\title{
Gambaran Kebugaran Jasmani Anak Usia Dini pada Masa Pandemi Covid-19
}

\author{
Wahyuni Ulpi ${ }^{1}$, Nurwahidin Hakim ${ }^{2}$, Abdul Kadir ${ }^{3}$, Hadi Pajarianto ${ }^{4}$, Rahmatia ${ }^{5}$ \\ Pendidikan Guru Pendididkan Anak Usia Dini Universitas Muhammadiyah Palopo(1,4,5) \\ Pendidikan Jasmani Universitas Muhammadiyah Palopo(2) \\ Bimbingan dan Konseling Universitas Muhammadiyah Palopo(3) \\ DOI: $10.31004 /$ obsesi.v6i1.1197
}

\begin{abstract}
Abstrak
Penelitian ini menganalisa gambaran kebugaran jasmani anak pada masa pandemi.Tujuan penelitian untuk mengetahui gambaran kebugaran jasmani anak usia dini pada masa pandemi covid-19. Metode yang digunakan jenis kualitiatif dengan pendekatan fenomenologi. Dengan teknik pengumpulan data observasi, wawancara dan dokumentasi. Sedangkan keabsahan datanya menggunakan triangulasi. Subjek penelitian berjumlah 3 informan orang tua dengan total orang. Kriteria sebagai berikut (1) memiliki anak usia 2-6 tahun. (2) laki-laki dan perempuan (3) tinggal bersama orang tua. Hasil penelitian informan(1)(4)(5)(6) menjaga kebugaran jasmani anak pada masa pandemi sedangkan informan(2) (3) tidak melakukan aktivitas untuk mencegah penularan COVID-19 dan kebugaran jasmani anak.
\end{abstract}

Kata kunci: kebugaran jasmani; covid-19; anak usia dini

\begin{abstract}
This research analyzes the overview of children's physical fitness during pandemic. The aim of this research is to know the physical fitness description of early childhood students in the era of Covid 19 pandemic. This research used qualitative method with phenomenology approach. Observation, interview and documentation are used as data collection technique. While for data validity used triangulation. The are 3 pairs of parents as subject in this research with the following criteria : 1 . They have children aged 2-6 years old. 2 . Boys and girls. 3. Living with their parents. The results of this research found that most of the parents keep their students health by keeping children's physical fitness during the pandemic while two of the parents do not do some activities for it.
\end{abstract}

Keyword: physical fitness; covid-19; early childhood

Copyright (c) 2021 Wahyuni Ulpi, Nurwahidin Hakim, Abdul Kadir, Hadi Pajarianto, Rahmatia

$\triangle$ Corresponding author :

Email Address : masganti@uinsu.ac.id (Medan, Sumatera Utara, Indonesia)

Received 14 March 2021, Accepted 17 March 2021, Published 22 March 2021 


\section{PENDAHULUAN}

Berbagai Negara di dunia terkena dampak COVID-19, China tercatat sebagai negara yang pertama kali melaporkan kasus Covid-19 di dunia. Untuk pertama kalinya, China melaporkan adanya penyakit baru ini pada 31 Desember 2019. Pada pengujung tahun 2019 itu, kantor Organisasi Kesehatan Dunia (WHO) di China mendapatkan pemberitahuan tentang adanya sejenis pneumonia yang penyebabnya tidak diketahui. Infeksi pernapasan akut yang menyerang paru-paru itu terdeteksi di kota Wuhan, Provinsi Hubei, China. Menurut pihak berwenang, beberapa pasien adalah pedagang yang beroperasi di Pasar Ikan Huanan (Glass et al., 2020). Selain China Negara Indonesia juga terdampak sejak februari 2020 yang hingga sekarang, yang mengakibatkan banyaknya aktivitas masyarakat tidak normal seperti sebelumnya (Kurniati et al., 2020). Salah satu cara untuk menghentikan penyebaran COVID-19 yaitu dengan membatasi aktivititas sosial dan melakukan karantina kepada orang-orang yang terjangkit. Indonesia sudah mengalami kondisi dimana kekhawatiran masyarakat terhadap COVID-19 cukup besar, sehingga diperlukan kebijakan pemerintah untuk melakukan lockdown, sebagai upaya memutus mata rantai penyebaran virus COVID-19. Wardani \& Ayriza (2020) Pembelajaran daring yang ditetapkan pemerintah, ditujukan kepada seluruh jenjang pendidikan dari TK hingga perguruan tinggi. Dipilihnya alternatif ini dikarenakan berkembangnya revolusi industri 4.0. Berkembangnya revolusi industri sangat mendukung terlaksananya pembelajaran daring dari rumah Situasi yang terjadi sekarang ini, justru akan menuntut keterlibatan orang tua secara lebih maksimal dan melakukan komunikasi yang lebih intens dengan guru dalam melaporkan perkembangan anaknya. Orang tua akan lebih aktif bekerja sama dengan guru ketika mendampingi anak di rumah. Dapat dikatakan pula bahwa situasi pandemi covid-19 ini mengembalikan hakikat pendidikan anak dalam keluarga. Langkah ini diambil karena aturan pemerintah yang melakukan pembatasan sosial berskala besar (PSBB).

Mutiah (2010) Anak usia dini merupakan usia yang memiliki rentang waktu sejak anak lahir hingga usia enam tahun, dimana dilakukan melalui pemberian rangsangan pendidikan untuk membantu pertumbuhandan perkembangan jasmani dan rohani agar anak memiliki kesiapan dalam memasuki pendidikan lebih lanjut. Anak usia dini rentang untuk terkena virus karena daya tubuh anak lemah dan sering beraktivitas yang berlebihan. Pada masa COVID-19 kesehatan ataupun imun tubuh anak harus terjaga sehingga tidak tertular virus. Kebugaran jasmani anak harus diperhatikan oleh orang tua karena merupakan hal yang dapat membantu imun tubuh agar tetap sehat dan kuat (Bluth \& Wahler, 2011). Pendidikan anak usia dini sangat penting karena masa golden age, anak suka meniru dengan apa yang mereka lihat sehingga orang tua lebih mudah untuk mengajarkan anak untuk menjaga kebugaran jasmani (Siti, 2017). Masa ini disebut masa keemasan sebab pada usia ini terjadi perkembangan yang sangat menakjubkan dan terbaik pada usia dini. Perkembangan yang menakjubkan tersebut mencakup perkembangan fisik dan psikis. Dari segi fisik anak mengalami perkembangan yang sangat luar biasa mulai dari pertumbuhan sel-sel otak dan organ tubuh lainnya sehingga perkembangan kemampuan motoric kasar seperti berjalan, berlari, melompat, memanjat dan sebainya. Inilah pentingnya perlu melihat dan memperhatikan kebugaran jasmani pada anak dimasa COVID-19 karena tubuh yang sehat akan berpengaruh pada perkembangan selanjutnya.

Paryanto \& Wati (2013) menyatakan kebugaran jasmani merupakan suatu keadaan yang sangat diinginkan oleh setiap orang, dengan kebugaran jasmani seseorang akan tampil lebih dinamis/semangat dan tercipta produktivitas kerja. Kebugaran jasamani salah satu cara untuk melawan COVID-19, dengan tetap rajin berolahraga setiap hari. Hal ini dapat dilakukan oleh orang tua untuk tetap menjaga kebugaran jasmani anak (Oktaviani, 2016). Dapat kita pahami bahwa sesungguhnya anak bukanlah miniatur orang dewasa, mereka mengalami pematangan dalam kecepatan yang berbeda dengan orang dewasa dan masa pubertss muncul setiap waktu 
dalam masa kira-kira 4 - 6 tahun. Kebugaran jasmani erat dikaitkan dengan kegiatan fisik (Sapto et al., 2020), kegiatan fisik sering didefenisikan sebagai setiap gerakan tubuh yang dihasilkan oleh oleh otot rangka yang menimbulkan pengeluran energy diatas nilai-nilai istirahat, aktivitas fisik adalah fenomena yang rumit yang bermakna dibagi kedalam kategori yang berbeda dan tingkat insensitas yang berbeda.Prinsip yang penting untuk melatih anak berolahraga yaitu dengan merangsang semua sistem organ dengan latihan bervariasi seperti aerobik, anaerobik, kekuatan, daya tahan, dan teknik. Program latihan yang dipaksakan pada anak sekalipun anak menyukainya, dapat memunculkan kerusakan organ tubuh. (Prasepty, 2017)Aktivitas fisik tak hanya berpengaruh terhadap tingkat kesehatan namun juga pada kemampuan kognitif, emosi dan social anak. Safitri \& Harun (2020) Peneliti terdahulu dengan judul "Membiasakan Pola Hidup Sehat dan Bersih Pada Anak Usia Dini Selama Pandemi COVID-19" dengan hasil penelitian bahwa membiasakan pola hidup sehat dan bersih pada anak pada masa pandemic COVID-19 dapat dilakukan dengan cara mengingatkan anak untuk memakan-makanan yang bergizi seperti sayuran dan buah, berolahraga teratur dan istirahat yang cukup serta melakukan berjemur setiap pagi hari sekitar 10-15 menit, mencuci tangan dengan sabun dan menjaga kebersihan diri sendiri, berbeda dengan penelitian ini yang memperhatikan kebugaran jasmani anak dengan melihat aktivitas rutin dan pembiasaan yang dilakukan oleh anak untuk pencegahan COVID-19.

\section{METODOLOGI}

Menggunakan Jenis penelitian deskriftif kualitatif, dengan jenis kualitiatif dengan pendekatan fenomenologi. (Albi Anggito, 2018) Penelitian kualitatif adalah pengumpulan data pada suatu latar alamiah dengan maksud menafsirkan fenomena yang terjadi dimana peneliti adalah sebagai instrument kunci, pengambilan sampel sumber data dilakukan secara purposive dan snowball. Subjek penelitian berjumlah 3 informan orang tua dengan total 6 orang yang terdiri dari 3 ibu dan 3 ayah. Kriteria sebagai berikut (1) memiliki anak usia 2-6 tahun. (2) laki-laki dan perempuan (3) tinggal bersama orang tua. Penelitian ini dilakukan di BTN Hartaco Kota Palopo. Dalam penelitian ini menganalisi kebuguran jasmani anak usia dini di masa COVID-19 dengan pendampingan orang tua.Teknik pengumpulan data yang digunakan yaitu Dokumentasi, wawancara dan observasi. Wawancara yang digunakan peneliti adalah wawancara tidak terstruktur yang merupakan Jenis wawancara bersifat fleksibel dan peneliti dapat mengikuti minat dan pemikiran partisipan, wawancara dilakukan kepada orang tua anak, serta observasi merupakan pengamatan yang dilakukan oleh peneliti dengan melihat subjek yang diteliti. (Sarwo, 2016) Wawancara merupakan salah satu teknik mengumpulkan informasi atau data melalui interaksi social antara peneliti dengan yang diteleti (Agusta, 2014). Teknik analisis data yang digunakan yaitu pengumpulan data, redukasi data, penyajian data dan penarikan kesimpulan. Selengkapnya dapat dilihat pada gambar 1.

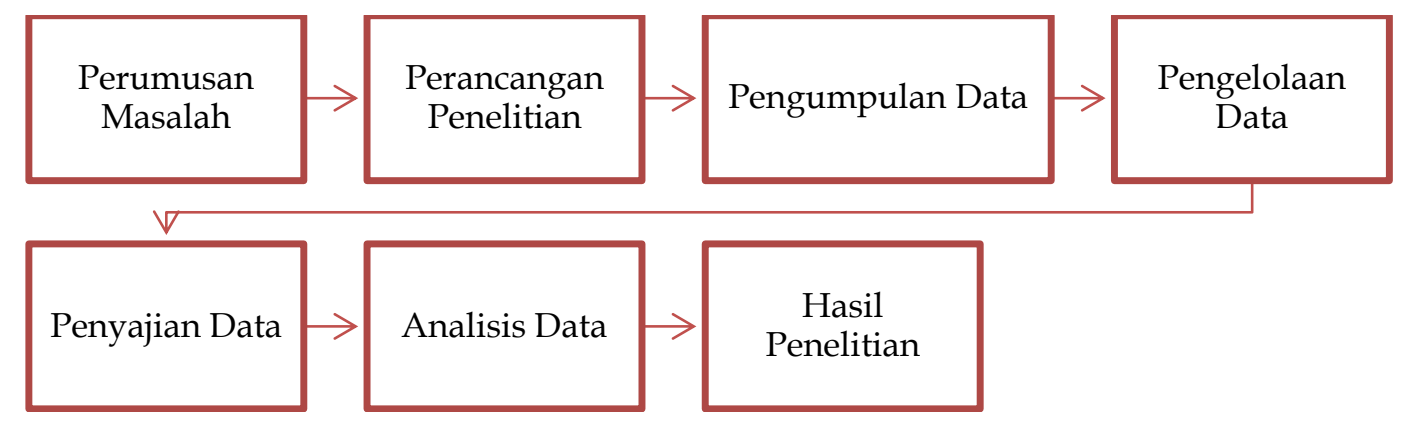

Gambar 1. Tahapan penelitian 


\section{HASIL DAN PEMBAHASAN}

Peristiwa COVID-19 mengharuskan banyak orang beraktivitas di rumah dengan tetap menjaga kebugaran jasmani. Informan 1 dan 2 adalah orang tua dari anak, Informan (1) berusia 35 tahun jenis kelamin perempuan. Informan(1) dan informan (2) mempunyai dua orang anak yang berusia 8 tahun dan 5 tahun. Informan(1) mempunyai anak perempuan dengan usia 5 tahun. Hasil wawncara informan (1) dapat dilihat pada tabel 3.1.

\section{Tabel 1. Hasil wawancara dengan informan (1)}

\begin{tabular}{|c|c|}
\hline Pertanyaan Peneliti & $\begin{array}{l}\text { Jawaban Informan I } \\
\end{array}$ \\
\hline $\begin{array}{l}\text { Apa yang anda pikirkan tentang } \\
\text { COVID-19? }\end{array}$ & COVID-19 adalah virus yang sangat mengerikan \\
\hline $\begin{array}{l}\text { Apakah perlu menjaga kebugaran } \\
\text { jasmani anak pada masa pande } \\
\text { mi? }\end{array}$ & $\begin{array}{l}\text { Ya, sangat perlu selama masa COVID-19 kami sebagai orang } \\
\text { tua sangat memperhatikan kesehatan anak sehingga } \\
\text { melakukan olahraga dipagi hari }\end{array}$ \\
\hline $\begin{array}{l}\text { Hal apa yang anda lakukan untuk } \\
\text { mencegah penularan COVID-19? }\end{array}$ & $\begin{array}{l}\text { aktivitas sehari-hari yang dilakukan oleh anak saya yang } \\
\text { berhubungan dengan kebugaran jasmani yaitu melakukan }\end{array}$ \\
\hline $\begin{array}{l}\text { Coba anda ceritkan aktivitas rutin } \\
\text { yang dilakukan untuk menjaga } \\
\text { kebugaran jasmani anak? }\end{array}$ & $\begin{array}{l}\text { kegiatan senam sederhana dibawah terik matahari antara } \\
\text { jam 06.30-07.30.Pada saat melakukan senam tidak } \\
\text { menggunakan musik/irama tetapi bergerak dengan } \\
\text { melakukan perhitungan seperti } 12345678 \text {, ini lakukan } \\
\text { secara berulang dan menggerakan tubuh. kegiatan ini rutin } \\
\text { dilakukan setiap pagi hari. anak saya suka dengan aktivitas } \\
\text { fisik yang dilakukan dan sudah menjadi kebiasaan selama } \\
\text { masa COVID-19 }\end{array}$ \\
\hline $\begin{array}{l}\text { Apakah selama wabah COVID-19 } \\
\text { menyerang anak anda pernah sakit? }\end{array}$ & $\begin{array}{l}\text { Ya, anak saya pernah droop selama } 3 \text { hari, tetapi saya tidak } \\
\text { membawahnya kedokter }\end{array}$ \\
\hline $\begin{array}{l}\text { Mengapa anda tidak membawanya } \\
\text { kedokter? }\end{array}$ & $\begin{array}{l}\text { Karena saya takut jika anak saya di test COVID dan sekarang } \\
\text { untuk kedokter juga sedikit khawatir takut tertular virus. }\end{array}$ \\
\hline
\end{tabular}

Informan (2) berusia 40 tahun jenis kelamin laki-laki, mempunyai dua orang anak yang berusia 8 tahun dan 5 tahun. Hasil wawancara informan (2) dapat dilihat pada tabel 2.

Tabel 2. Hasil wawancara dengan informan (2)

\begin{tabular}{|c|c|}
\hline Pertanyaan Peneliti & Jawaban Informan 2 \\
\hline $\begin{array}{l}\text { Apa yang anda pikirkan tentang } \\
\text { COVID-19? }\end{array}$ & $\begin{array}{l}\text { Virus yang dapat menular kesemuan orang baik orang tua, } \\
\text { remaja maupun anak-anak }\end{array}$ \\
\hline $\begin{array}{l}\text { Apakah anda mendampingi anak } \\
\text { dirumah? }\end{array}$ & $\begin{array}{l}\text { Saya mendampingi anak jika malam hari atau pada saat hari } \\
\text { libur }\end{array}$ \\
\hline $\begin{array}{l}\text { Apakah COVID-19 berbahaya untuk } \\
\text { anak? }\end{array}$ & $\begin{array}{l}\text { Ya, Karena imun tubuh anak itu rendah sehingga rentang } \\
\text { untuk tertular }\end{array}$ \\
\hline $\begin{array}{l}\text { Bagimana cara mendampingi anak } \\
\text { selama masa pandemi COVID-19 agar } \\
\text { anak tetap sehat dan tidak terjangkit } \\
\text { virus dan kebugaran jasmani anak } \\
\text { terjaga? }\end{array}$ & $\begin{array}{l}\text { saya tidak banyak berperan pada saat mendampingi anak } \\
\text { karena saya sibuk bekerja sehingga aktivitas keseharian } \\
\text { anak didampingi oleh ibunya }\end{array}$ \\
\hline $\begin{array}{l}\text { Apakah anak anda pernah sakit selama } \\
\text { wabah virus? }\end{array}$ & Seingat saya pernah tapi hanya beberapa hari \\
\hline
\end{tabular}

Hasil pengamatan yang dilakukan peneliti melihat aktivitas keseharian anak lebih banyak dengan ibunya karena ayahnya sibuk bekerja. Peneliti melihat bahwa dengan gerakan senam 
dilakukan anak terlihat berkeringa melakukan kegiatan senam anak melanjutkan dengan bermain sepeda sekitar 10 menit.(Endang Rini Sukamti, Muhammad Ikhwan Zein, 2016) Seseorang yang bugar dalam kaitannya olahraga dan aktivitas fisik diartikan sebagai orang yang mampu menjalankan kehidupan sehari-hari tanpa melampaui batas daya tahan stress pada tubuh yang memiliki tubuh yang sehat serta tidak berisiko mengalami penyakit yang disebabkan rendahnya tingkat kebugaran atau kurangnya aktivitas fisik. Peneliti menyimpulkan bahwa informan(1) memperhatikan aktivitas yang dapat menjaga kebugaran jasmani anak. Informan (2) tidak berperan dalam pencegahan COVID-19 karena informan(2) sibuk bekerja. Namun kebugaran jasmani anak tetap terjaga pada masa pandemi karena informan(1) selaku orang tua melakukan pencegahan dengan rutin melakukan kegiatan senam setiap pagi.

Informan (3) berusia 25 tahun jenis kelamin perempuan, mempunyai anak yang berusia 4 tahun. Hasil wawancara informan (3) dapat dilihat pada tabel 3.

Tabel 3. Hasil wawancara dengan informan (3)

\begin{tabular}{ll}
\hline \multicolumn{1}{c}{ Pertanyaan Peneliti } & \multicolumn{1}{c}{ Jawaban Informan 3 } \\
\hline $\begin{array}{l}\text { Apa yang anda pikirkan tentang } \\
\text { COVID-19? }\end{array}$ & $\begin{array}{l}\text { COVID-19 antara ada dan tiada, saya tidak percaya } \\
\text { adanya COVID-19 seperti yang diberitakn di televisi }\end{array}$ \\
$\begin{array}{l}\text { Mengapa anda tidak percaya dengan } \\
\text { COVID-19? }\end{array}$ & $\begin{array}{l}\text { Karena sangat banyak berita hoaks yang ada di televise, } \\
\text { saya juga melihat banyak orang sehat tetapi divonis } \\
\text { COVID. }\end{array}$ \\
$\begin{array}{l}\text { Selama pandemi COVID-19 untuk } \\
\text { aktivitas sehari-hari anak saya normal, tidak ada } \\
\text { yang anda lakukan? }\end{array}$ & $\begin{array}{l}\text { perbedaan sebelum pandemi dan pada masa pandemi } \\
\text { sekarang, Hal yang berbeda hanyalah aktivitas disekolah } \\
\text { dilakukan dirumah }\end{array}$ \\
$\begin{array}{l}\text { Apakah tidak ada kekhawatiran jika karena selama ini anak saya sehat-sehat saja } \\
\text { anak anda terinveksi COVID-19? }\end{array}$ & $\begin{array}{l}\text { sedangkan COVID-19 diberitakan sudah beberapa bulan } \\
\text { ada } \\
\text { Pernah, cumam demam biasa, kompres dan beri obat } \\
\text { penurun panas sembuh, anak saya sakit karena sering } \\
\text { menyerang anak anda pernah sakit? }\end{array}$ \\
\hline
\end{tabular}

Informan(4) berusia 27 tahun jenis kelamin laki-laki, Hasil wawancara informan (4) dapat dilihat pada tabel 4 .

Larasati et al. (2020) COVID-19 merupakan penyakit yang disebabkan oleh jenis virus corona yang menyerang ke system pernapasan, virus corona sebenarmya pertama kali diidentifikasi pada tahun 1960-an. Peneliti menyimpulkan bahwa informan (3) tidak memperhatikan kegiatan yang dapat menjaga kebugaran jasmani anak dan informan (4) memperhatikan keseharian anak untuk menjaga kebugaran jasmani. Namun kebugaran jasmani anak tetap terjaga pada masa pandemi karena informan(4) selaku orang tua melakukan pencegahan dengan menjaga kebersihan dan memeperhatikan anak untuk memperbanyak minum air putih.

Informan(5) berusia 24 tahun jenis kelamin perempuan,. Masa pandemi COVID-19 merupakan kehidupan baru yang harus dihadapi dengan beberapa aktivitas baru, Hasil wawancara informan (5) dapat dilihat pada tabel 5.

Inten \& Permatasari (2019) Pola makan orang tua dirumah akan diikuti oleh anak dalam kesehariaanya, oleh karena itu orang tua terutama ibu sebaiknya memiliki pengetahuan tentang gizi seimbang agar anak dapat menghidangkan makanan yang penuh gizi dan sehat untuk anak. Informan(5) menyediakan makanan yang sehat seperti rutin mengkonsumsi buah setiap harinya. 
Tabel 4. Hasil wawancara informan (4)

\begin{tabular}{|c|c|}
\hline Pertanyaan Peneliti & Jawaban Informan 4 \\
\hline $\begin{array}{l}\text { Apa yang anda pikirkan tentang } \\
\text { COVID-19? }\end{array}$ & $\begin{array}{l}\text { COVID-19 merupakan wabah yang sangat berbahaya pada manusia } \\
\text { utamanya pada anak dan lansia, sehingga perlu adanya pencegahan dini } \\
\text { yang kami lakukan selaku orang tua untuk tetap menjaga kebugaran anak }\end{array}$ \\
\hline $\begin{array}{l}\text { Bagaimana kesehatan anak anda } \\
\text { selama wabah COVID-19? }\end{array}$ & $\begin{array}{l}\text { Alhmdulillah selama masa pandemi ini anak saya sehat dan beraktivitas } \\
\text { seperti biasanya }\end{array}$ \\
\hline $\begin{array}{l}\text { Selama pandemi COVID-19 } \\
\text { untuk menjaga kesehatan anak } \\
\text { apa yang anda lakukan? }\end{array}$ & $\begin{array}{l}\text { Untuk mencegah terkenanya virus yang saya lakukan kepada anak } \\
\text { saya yaitu mengajak anak rajin cuci tangan, menjaga kebersihan } \\
\text { dan memperbanyak minum air putih. Kegiatan ini dijadikan } \\
\text { aktivitas kebiasaan bagi anak untuk mencegahan COVID-19 }\end{array}$ \\
\hline $\begin{array}{l}\text { Apakah tidak ada kekhawatiran } \\
\text { jika anak anda terinveksi COVID- } \\
19 ?\end{array}$ & $\begin{array}{l}\text { Sangat khawatir karena wabah ini belum ada vaksin atau obat yang } \\
\text { cocok. }\end{array}$ \\
\hline $\begin{array}{l}\text { Apakah selama wabah COVID-19 } \\
\text { menyerang anak anda pernah } \\
\text { sakit? }\end{array}$ & Pernah, mungkin karena sering bermain diluar rumah \\
\hline
\end{tabular}

Tabel 3.5. Hasil wawancara informan (5)

\begin{tabular}{l} 
Pertanyaan Peneliti \\
\hline Apa yang anda pikirkan tentang \\
COVID-19? \\
apakah perlu menjaga kebugaran \\
jasmani anak pada masa sekarang?,
\end{tabular}
jasmani anak pada masa sekarang?,

Makan bergizi yang anda maksud seperti apa?

COVID-19 adalah virus yang sangat cepat menyebar dan berbahaya untuk kesehatan, yang saya liat di tv dan sosial media sudah sangat banyak korban yang meninggal dunia, bukan hanya di Indonesia tetapi juga dinegara lain

Tentu saja sangat perlu, hal yang saya lakukan untuk anak saya selama masa pandemi yaitu memperhatikan pola makan anak dengan menerapkan makanan empat sehat lima sempurna. Makanan yang bergizi penting untuk anak usia dini karena kualitas gizi memberikan tumbuh kembang serta kesehatan anak dimasa depan

Sayur-sayuran dan buah-buahan perlu dimakan setiap hari karena makanan ini kurang mengandung lemak dan mengandung vitamin, zat-zat dan serat yang sangat penting untuk kesehatan. Makanan yang mengandung rendah lemak adalah tahu atau kacang soya, kacang-kacangan, ikan, biji-bijian, sayuran dan buah-buahan

Apakah tidak ada kekhawatiran jika anak anda terinveksi COVID-19?

Apakah selama wabah COVID-19 Al kesehatan anak saya terjaga menyerang anak anda pernah sakit?

informan (6) berusia 35 tahun jenis kelamin laki-laki mempunyai 2 orang anak yang berusia 6 bulan (laki-laki) dan 6 tahun (perempuan). , Hasil wawancara informan (6) dapat dilihat pada tabel 6.

Kaunang et al. (2020) Untuk meningkatkan fungsi system imun perlu mengkomsumsi vitamin yang kaya dalam makanan maupun suplemen seperti vitamin C, Vitamin B3, vitamin B5, Vitamin B6, dan Vitamin E.selain memberian vitamin informan(6) menjaga lingkungan rumah tetap bersih. peneliti menyimpulkan bahwa informan(5) menjaga kebugaran jasmani anaknya dimasa pandemi COVID-19 dengan memperhatikanan makanan yang bergizi untuk anak sedangkan informan(6) memberikan vitamain untuk anak. Sehingga kebugaran jasmani anak 
tetap terjaga pada masa pandemi karena selaku orang tua melakukan pencegahan dengan memeperhatikan makanan yang bergizi untuk dan memberikan vitamin untuk anak.

Table 6. Hasil wawancara informan (6)

\begin{tabular}{|c|c|}
\hline Pertanyaan Peneliti & Jawaban Informan 5 \\
\hline $\begin{array}{l}\text { Apa yang anda pikirkan tentang } \\
\text { COVID-19? }\end{array}$ & $\begin{array}{l}\text { COVID-19 sungguh meresahkan karena menghambat } \\
\text { aktivitas setiap harinva }\end{array}$ \\
\hline $\begin{array}{l}\text { apakah perlu menjaga kebugaran } \\
\text { jasmani anak pada masa sekarang?, }\end{array}$ & $\begin{array}{l}\text { Tentu perlu, kita sebagai orang tua harus melakukan } \\
\text { pencegahan dini untuk anak }\end{array}$ \\
\hline $\begin{array}{l}\text { Hal apa yang anda lakukan untuk } \\
\text { menjaga kebugaran jasmani anak? }\end{array}$ & $\begin{array}{l}\text { Memberikan vitamin c kepada anaknya untuk mencegah } \\
\text { tertularnya COVID-19. Hal ini dilakukan agar tubuh anak } \\
\text { tetap bugar sehingga dapat melawan penyakit yang akan } \\
\text { masuk kedalam tubuhnya }\end{array}$ \\
\hline $\begin{array}{l}\text { Apakah tidak ada kekhawatiran jika } \\
\text { anak anda terinveksi COVID-19? }\end{array}$ & Sangat khawatir karena saya sangat takut dengan virus ini \\
\hline $\begin{array}{l}\text { Apakah selama wabah COVID-19 } \\
\text { menyerang anak anda pernah sakit? }\end{array}$ & Anak saya pernah dirawat di rumah sakit \\
\hline
\end{tabular}

\section{SIMPULAN}

Simpulan penelitian ini mendapatkan temuan baru yaitu ada dua informan yang tidak memperhatikan kebugaran jasmani anak pada masa pandmei COVID-19 dan empat informan yang melakukan mencegahan COVID-19. Informan(1)melakukan pencegahan dengan rajin melakukan kegiatan senam bersama anak,informan(2)tidak melakukan pencegahan karena sibuk bekera, informan(3)tidak melakukan pencegahan COVID-19, informan(4)melakukan pencegahan dengan rajin mencuci tangan dan mengkomsumsi air putih, informan(5) mejaga kebugaran jasmani anak dengan memberikan makanan bergizi seperi sayuran dan buah-buahan, serta informan(6) menjaga kebugaran jasmani anak dengan memberikan vitamin $\mathrm{C}$ dan menjaga kebersihan disekitar lingkungan rumah.

\section{UCAPAN TERIMA KASIH}

Terima kasih kepada informan yang telah bersedia untuk membantu jalannya penelitian dan terima kasih kepada jurnal obsesi yang telah memberikan wadah sehingga dapat dibaca oleh khalayak khususnya untuk menjaga kebugaran jasmani pada anak dimasa pandemic COVID-19.

\section{DAFTAR PUSTAKA}

Gusta, I. (2014). Teknik Pengumpulan dan Analisis Data Kualitatif. Jurnal Studi Komunikasi Dan Media, 02(1998), 1-11.

Albi Anggito, J. S. (2018). Metodologi penelitian kualitatif - Albi Anggito, Johan Setiawan. In CV . Jejak (p. 214).

Bluth, K., \& Wahler, R. G. (2011). Does Effort Matter in Mindful Parenting? Mindfulness, 2(3), 175178. https://doi.org/10.1007/s12671-011-0056-3

Endang Rini Sukamti, Muhammad Ikhwan Zein, R. B. (2016). Profil Kebugaran Jasmani Dan Status Kesehatan Instruktur Senam Aerobik Di Yogyakarta. In Jurnal Olahraga Prestasi (Vol. 12, Issue 2, p. 116313). https://doi.org/10.21831/jorpres.v12i2.11875

Glass, C. A., Cash, J. C., \& Mullen, J. (2020). Coronavirus Disease (COVID-19). In Family Practice Guidelines. https:// doi.org/10.1891/9780826153425.0016b 
DOI: 10.31004/obsesi.v6i1.1197

Inten, D. N., \& Permatasari, A. N. (2019). Literasi Kesehatan pada Anak Usia Dini melalui Kegiatan Eating Clean. Jurnal Obsesi : Jurnal Pendidikan Anak Usia Dini, 3(2), 366. https://doi.org/10.31004/obsesi.v3i2.188

Kaunang, T. A. S., Kapantow, N. H., \& Langi, F. (2020). Asupan Vitamin Larut Air Pada Tenaga Pendidik Dan Kependidikan Fkm Unsrat Saat Pembatasan Sosial Masa Pandemi Covid19. In Kesmas. https://ejournal.unsrat.ac.id/index.php/kesmas/article/view/31616

Kurniati, E., Nur Alfaeni, D. K., \& Andriani, F. (2020). Analisis Peran Orang Tua dalam Mendampingi Anak di Masa Pandemi Covid-19. Jurnal Obsesi : Jurnal Pendidikan Anak Usia Dini, 5(1), 241. https:// doi.org/10.31004/obsesi.v5i1.541

Larasati, A. L., Gozali, D., \& Haribowo, C. (2020). Penggunaan Desinfektan dan Antiseptik Pada Pencegahan Penularan Covid-19 di Masyarakat. Majalah Farmasetika, 5(3). https://doi.org/10.24198/mfarmasetika.v5i3.27066

Mutiah, D. (2010). Psikologi Bermain Anak Usia Dini (Pertama). Prenada Media Group.

Oktaviani, J. (2016). Tinjauan Buku. Jurnal Dinamika Global, 1(02), 141-146. https://doi.org/10.36859/jdg.v1i02.29

Paryanto, R., \& Wati, I. D. P. (2013). Upaya Meningkatkan Kebugaran Jasmani Siswa Melalui Pendidikan Jasmani. Jurnal Pendidikan Dan Pembelajaran Untan, 2(5), 143-154.

Prasepty, W. (2017). Pengembangan Instrumen Tes Kebugaran Jasmani untuk Anak TK Usia 4-6 Tahun. In Journal of Physical Education and Sports (Vol. 6, Issue 2, pp. 205-210).

Safitri, H. I., \& Harun, H. (2020). Membiasakan Pola Hidup Sehat dan Bersih pada Anak Usia Dini Selama Pandemi Covid-19. Jurnal Obsesi : Jurnal Pendidikan Anak Usia Dini, 5(1), 385. https://doi.org/10.31004/obsesi.v5i1.542

Sapto, A., Supriyadi, \& Masgumelar, N. (2020). Model-Model Exercise dan Aktivitas Fisik untuk Kebugaran Jasmani Anak SD.

Sarwo, E. F. R. (2016). Teori Wawancara Psikodignostik. In PT Leutika Nouvalitera.

Siti, M. (2017). Psikologi Perkembangan Anak Usia Dini Edisi Pertama. In Yogyakarta: Gava Media.

Wardani, A., \& Ayriza, Y. (2020). Analisis Kendala Orang Tua dalam Mendampingi Anak Belajar di Rumah Pada Masa Pandemi Covid-19. Jurnal Obsesi : Jurnal Pendidikan Anak Usia Dini, 5(1), 772. https://doi.org/10.31004/obsesi.v5i1.705 